\title{
THE CONTRIBUTION OF ANXIETY TO ENGLISH TEXT COMPREHENSION ABILITY
}

\author{
Supeno; Imam Suseno \\ Program of English Education, Faculty of Language and Art, University of Indraprasta PGRI \\ Jalan Nangka No. 58C Tanjung Barat, Jagakarsa, South Jakarta 12530 \\ supenofbs@gmail.com, susenoblr@gmail.com
}

\begin{abstract}
This study aims to understand how anxiety as a variable contributes to affecting the ability to comprehend English texts using the ex post facto method, with eleventh grade high school students in Jakarta as the respondents. Students' anxiety is measured based on behavioral and cognitive characteristics listed on the questionnaire given to respondents along with the English test. The results show that there is indeed a difference in anxiety levels on students in working on the various English text comprehension tests given. The results of the English text comprehension tests are generally influenced by the anxiety variable, although the effect is found to be small. Teachers are recommended to use multiple teaching methods, and to teach and to motivate the students to read more. Teachers are also recommended to apply multiple variations of ability evaluation in measuring the students' English text comprehension by using multiple test modes.
\end{abstract}

Keywords: student's anxiety, English text comprehension, ex post facto method

\begin{abstract}
ABSTRAK
Penelitian ini bertujuan untuk memahami bagaimana kecemasan sebagai variabel berkontribusi mempengaruhi kemampuan memahami teks-teks bahasa Inggris menggunakan metode ex post facto dengan siswa sekolah menengah kelas sebelas sebagai responden. Kecemasan siswa diukur berdasarkan karakteristik perilaku dan kognitif yang tertera pada kuesioner yang diberikan kepada responden bersamaan dengan tes bahasa Inggris. Hasilnya menunjukkan adanya perbedaan tingkat kecemasan pada siswa dalam mengerjakan berbagai tes pemahaman teks bahasa Inggris yang diberikan. Hasil tes pemahaman teks bahasa Inggris umumnya dipengaruhi oleh variabel kecemasan meskipun efeknya ditemukan hanya sebagian kecil. Guru disarankan untuk menggunakan berbagai metode pengajaran dan untuk mengajar serta memotivasi siswa untuk membaca lebih banyak. Guru juga disarankan untuk menerapkan beberapa variasi evaluasi kemampuan dalam mengukur pemahaman teks bahasa Inggris siswa dengan menggunakan beberapa mode tes.
\end{abstract}

Kata Kunci: kecemasan siswa, pemahaman teks bahasa Inggris, metode ex post facto 


\section{INTRODUCTION}

Language is a tool to deliver one's mind, ideas, or feelings. As it is mentioned by Setiadi (2006:10), "Language is a system to express meaning. One may deliver what he feels to others through the use of language". For instance, anger, joy, happiness, sorrow, and so on can be expressed with language so that others understand what one feels.

English plays the role of a pivotal international communication media capable of creating the proper and conducive atmosphere for discussion amongst those who learn the language. English is the official language of many commonwealth countries and is understood and widely used around the world. English is thus one of the most commonly used languages in the world.

Hence, English education becomes one of the mandatory curricula for students in Indonesia, especially for high schools in Jakarta. Scrivener (2005) believes that English education should be designed to give the chance for the students to improve their skills in using the language, dubbed language skills. These language skills are described as what we do with the language. One's ability in comprehending English texts is among the important factors in learning a language, because realistically, daily activities tend to require one to tune in and to understand the point of what another tries to communicate to them through the extensive use of said language. Thus, English education requires understanding in regards to language skills, especially in the context of learning activity.

Comprehending English texts can be learned through learning to read properly and carefully to discern ideas, points, and the general feelings that the writer intends to convey. Understanding the contents of a sentence is not simply knowing the meaning of each and every word in the text, but also to understand the general content of said English text. The ability to comprehend English texts on students can be properly detected through continuous evaluation of the students' studies. Ebel in Somadoyo (2010) stated that there are factors that influence a student's potential text comprehension capability and their interest on reading, such as (a) the student's predispositions, (b) their family, (c) their cultural background, and (d) their school situations. The inability to properly concentrate may be caused by the aspect of anxiety, which may cause the students to fail to understand the contents of a message or news in an English text.

A student's true ability can be seen through their performance in a test administered to them. The results, in the form of scores, can then be converted into their grades, which can then be fitted into criteria ranging from excellent to very bad. However, these scores do not necessarily reflect the students' true capabilities. The results can also be a product of the students (a) cheating, (b) working in a hurry, (c) making careless or carefree mistakes, (d) underestimating the test's difficulty level, (e) feeling anxious about a particularly difficult item, and so on and so forth.

Study examinations as an evaluation platform is known to be diverse. Multiple-choice test, for example, is known to be among the most commonly used type of test, given that it has certain characteristics: (a) it is quick to correct and to evaluate, (b) it can be used for large amounts of students to measure their abilities at once, and (c) it can be quickly processed to also quickly discern the students' ability levels. The items of multiple-choice tests have certain advantages over other tests. For example, this type of test allows for measuring the different variance in learning outputs among students, from the simple to the complex, and its form and function is adaptable to suit the contents of the evaluated learning material. This involves a wide range of applications and special uses, to the point that some standardized tests use the multiple-choice format. 
The measurement of foreign language anxiety is based on the development and integration of the idea of psychological anxiety as formulated by Stuart and developed by Horwitz and Cope (1986). Stuart classified foreign language anxiety into four scales of Likert measurement, which are Not Anxious, Typical, Anxious, and Panicking. In the other hand, Horwitz and Cope classified it into five Likert scales in 33 items, aiming to investigate the students' experience of anxiety in regards to foreign language anxiety in the classroom. He developed this into the Foreign Language Classroom Anxiety Scale (FLCAS).

The measurement of foreign language anxiety is based on the students' capability of speech and their attitude, in line with Horwitz's and Cope's ideas as follows: Foreign language anxiety concerns performance evaluation within an academic and social context. It is useful to draw parallels between it and three related performance anxieties: 1) communication apprehension, 2) test anxiety, and 3) fear of negative evaluation. Due to its emphasis on interpersonal interactions, the construct of communication apprehension is quite relevant to the conceptualization of foreign language anxiety. This research aims to analyze anxiety as a variable that influences students' English text comprehension on high school students in Jakarta.

\section{METHOD}

The research uses ex post facto method, taking data of the students' test results while also giving them relevant questionnaires with the research instruments. The gathered research data will be analyzed to discover the contribution of anxiety in affecting the students' performance in various multiplechoice English text comprehension tests on eleventh grade high school students in East Jakarta.

Research was performed in the duration of five months, beginning from October 2018 and finishing at February 2019. The locations used as research objects are the national high schools SMAN 93, SMAN 50, and SMA Pusaka in East Jakarta. Sampling method used in this research is cluster random sampling, resulting in the said three high schools. In total, 125 students are the representative samples used in this research.

The data gathered in this research is quantitative in nature. They are obtained from the questionnaire that students fill about their anxiety in working on English text comprehension in several test varieties, namely multiple-choice (MC), fill-in-the-blank (FTB), and true/false (TF) tests. Meanwhile, the anxiety data is obtained from the questionnaire distributed in the end of the English text comprehension tests given out by the class teacher.

\section{RESULTS AND DISCUSSION}

Student's anxiety is measured through behavioral aspects and the cognitive characteristics which can be discerned in the questionnaire instrument, which was given after the students finished their English text comprehension tests. Indicators of anxiety on behavioral aspects and cognitive characteristics can be seen in the analysis results of the students' answers, which are a) feeling uncomfortable about working on English tests, b) feeling nervous, c) feeling uneasy after working on a test, d) fearing bad grades or failing the test, e) perspiring more than usual, and f) not entirely focused in working on the English test.

Results of the descriptive data analysis show that there is indeed variance in students' anxiety in working on English text comprehension tests. 
Table 1

Descriptive Data Summary

\begin{tabular}{|c|c|c|c|c|c|}
\hline \multicolumn{2}{|l|}{ Anxiety } & \multicolumn{2}{|c|}{ English test score } & \multirow{2}{*}{ Regression equation } & \multirow{2}{*}{$\mathrm{R}^{2}$} \\
\hline Mean & Stdev & Mean & Stdev & & \\
\hline 79,38 & 12,25 & 62,56 & 16,75 & $Y=64,5+0,238 X$ & $10,6 \%$ \\
\hline
\end{tabular}

The summary above showed that there is variance of students' anxiety score means in working on the various English text comprehension tests. The anxiety reported averages at 79.38, which signifies high levels of anxiety. This means the students are feeling uncomfortable about working on
English tests, feeling nervous, feeling uneasy after working on a test, fearing bad grades or failing the test, which hinder their ability to focus on the test entirely. The distribution of students' anxiety on working the English text comprehension test can be seen on the figure below.

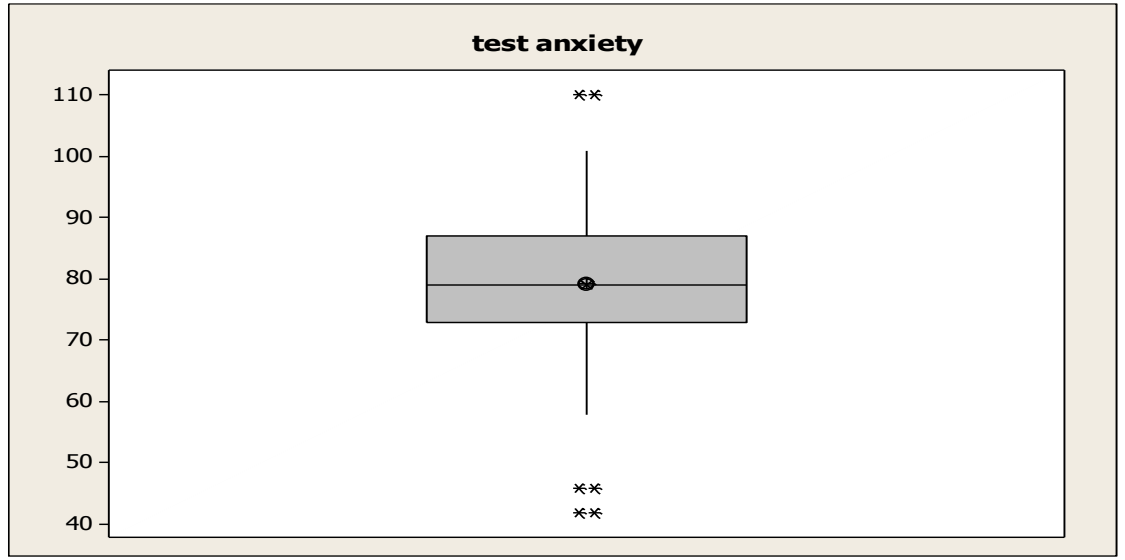

Figure 1

Students' Anxiety Distribution

These results are similar with Hidayati in Mardhatillah (2015), which used the foreign language anxiety scale with indicators for cognitive, affective, and psychomotor manifestations; mental stress, difficulties concentrating, confusion in answering test items, and excessive fear and nervousness; and fear of negative evaluation with indicators for anxiousness due to assumptions regarding the social situation and being judged by others, not gaining the approval of others, doing something embarrassing in public, being criticized, and being unsupported or rejected.
These results show consistency with the views expressed by Budiman (2015), who stated that anxiety is a normal reaction to particularly press situations in one's life. Aside from being a normal reaction, anxiety is also a psychological or mental symptom in preventive measures against unexpected or undesired things or events, and the discomfort in one's emotional condition is marked by other psychological signs, such as fear, worry, anxiety, nervousness, lack of self-esteem, all the way to the higher levels, which are stress, depression, and panic.

Along the same lines, Ramsay (2003:1) stated that "Anxiety is a 
feeling of fear, dread, or uneasiness, and some anxious people suffer from conditions, phobias, stress, sadness, panic, and depression". Anxiety is the feeling of fear and nervousness, and people with anxiety also tend to suffer from conditions like phobia, stress, sorrow, panic, and depression.

In a research, Mardhatillah (2015) stated that foreign language anxiety arises because of psychological factor, namely lower self-efficacy in comparison to one's actual ability. Furthermore, it is mentioned that there is a negative relationship between selfefficacy and foreign language anxiety. In other words, the higher the selfefficacy, the lower a student's foreign language anxiety is; vice versa, the lower the self-efficacy, the higher the foreign language anxiety. Mardhatillah (2015) concluded that self-efficacy is a factor that influences foreign language anxiety.

Meanwhile, the results of English text comprehension test produce a mean result of 62.56 with a standard deviation of 16.75 , meaning that the MC type test has a variance in students' score distribution. The influence of anxiety to the MC type test results is found to be $10.6 \%$, or that $89.4 \%$ is influenced by other variables aside from anxiety.

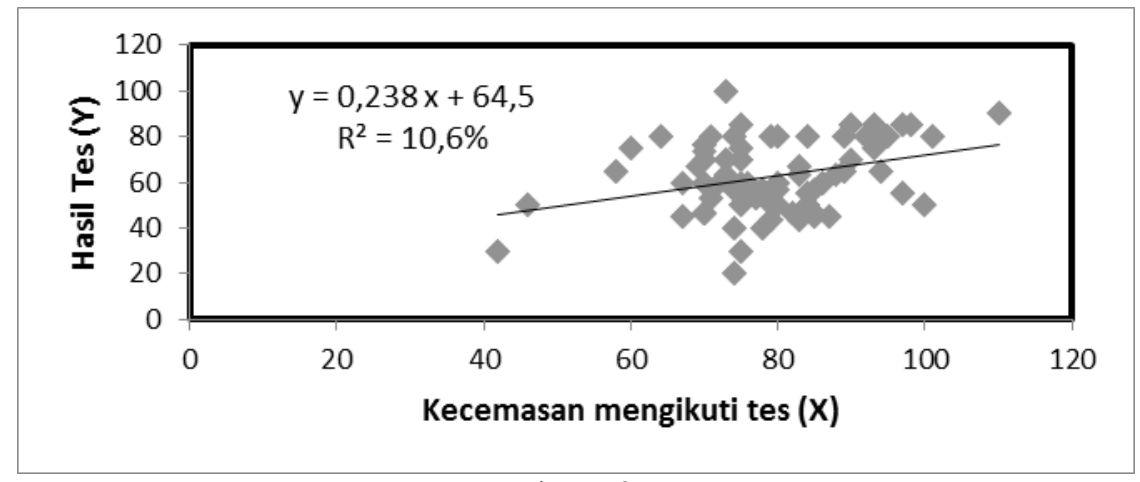

Figure 2

Students' Anxiety (X) Related to the Test Results (Y)

The characteristics of an MC test includes several options to pick as the answer and that there is also the element of distraction options, which may influence a student to lose their concentration due to anxiety over their own capabilities, which may hinder them from performing optimally and obtaining proper grades. Suseno (2017) explained that the characteristics of MC test allows for multiple different options that have a certain degree of similarity to be fitted into the item, making it harder to find the proper answer to the question because some of the options may seem 'almost right'. Although the influence of anxiety to the test results is relatively small, these presses the role of the teachers to give the students more confidence in working on MC tests.

In an attempt to reduce nervousness and fear when students face a classroom language situation, the techniques commonly used to relax is to take one or two deep breaths, which then leads to the students collecting themselves and staying calm. "By being relaxed, it is likelier for the students to be able to function cognitively, and therefore perform in a more controlled and structured way" (Sembodo, 2018:9).

Said anxiety can cause the students to go through a particularly bad 
experience in classroom foreign language use, or to cause them to worry about their seeming lack of knowledge and fluency in regards to the language, which means that language anxiety itself can influence achievements in learning, and inadequate ability can cause anxiety, worry, fear, and loss of concentration. An individual will fear making mistakes and fear becoming the butt of a joke to the audience who see them using a second language. This echoes the statement by Spielberger (2004) that foreign language anxiety is a feeling that arises within an individual in the form of tautness, fear, nervousness, and worry, which were all connected to the autonomic nervous system. One of the factors influencing anxiety is, indeed, self-efficacy.

Clarke, et. al. (1996:38) explained that "Reading is connected to lexical understanding and content understanding". Lexical understanding regards the process of how one recognizes the written symbols and translate them to the spoken language. Content understanding regards the understanding of how the words and sentences connect to become a readable text.

Arguments about why anxiety cases tend to happen in the classroom of second or foreign language is put forth by Guiora in Sembodo (2018), who made it clear that language learning is a worrying psychological problem because it directly threatens one's concept of self and worldviews. The anxious students tend to believe that learning a language is always difficult, so they tend to feel down and incapable when learning a second or foreign language. This assumption is partly influenced by a history of frustration in language learning, which in turn would drive the students into difficulty in learning language. Apart from the possibility that anxiety in testing also contributes to when they take the test, their low grades show that the materials taught are not absorbed and processed.

The most rational alternative solution to minimize the amount of anxiety the students go through can be done by creating a fun learning method, by using more varieties to evaluate their English text comprehension ability, and by encouraging the teachers to teach the students to read more as a hobby to pique interest. When the basic principles of English teaching can be sustained and continuously used, students' results will be optimal because of the minimized anxiety. In terms of increasing students' English text comprehension ability, alternatives such as reading strategies can be used in order to stimulate cognitive growth through six steps, which are fully understanding a text, understanding the meaning within context, to think and deduce the meaning, to contextually seek the meaning, to further investigate the meanings, and to return to thoughts of lexical meaning (Supeno, Suseno and Alhamidi, 2017).

\section{CONCLUSION}

Student's anxiety in the studies are marked by nervousness, worry, and baseless fear that undesired or unexpected things would happen. We found a $10.6 \%$ contribution of anxiety to the students' English text comprehension test results. On the measurement scale, their anxiety can be classified as high. Students can try to minimize anxiety when starting the test, for instance by taking a deep breath. The teachers should also take the proactive role in minimizing student anxiety through fun learning and applying active-student learning method, where the students are encouraged to be participate actively in 
the learning process. The teachers can also use other methods such as increasing the number of variants for English capability evaluations by utilizing multiple test types, and by inciting interest among students to read more language text books.

\section{REFERENCES}

Budiman, M. (2015). Kecemasan Berbahasa Asing (Bahasa Arab). Universitas Muhammadiyah Semarang.

Clarke, M. A., et al. (1996). Choice Readings. Singapore: STI Publishers. Pte. Ltd.

Horwitz, E. K., Horwitz, M. B., \& Cope J. (1986). Foreign language classroom anxiety. The Modern Language Journal, 70(2), 125132.

Mardhatillah, H. (2015). Hubungan antara Self-Eficacy dengan Kecemasan Berbahasa Asing Pada Santri Baru Pondok Pesantren Nahdhatul Muslimat Surakarta. Universitas Muhammadiyah Surakarta.

Ramsay, A. (2003). HELP FOR ANXIOUS PEOPLE Literacy and Life Skills Workbook 3. UNESCO Office for the Caribbean Kingston. Jamaica: Morton Publishing.
Scrivener, J. (2005). Learning Teaching: A Guide Book for English Language Teachers. Oxford, UK: Macmillan Education.

Sembodo, T. J. P. (2018). Dampak dan strategi untuk mengatasi kecemasan berbicara dalam pembelajaran bahasa Inggris sebagai bahasa ke-2 (ESL) dan asing (EFL). Jurnal Lingua Aplicata 2(2).

Setiadi, Ag. B. (2006). Teaching English as Foreign Language. Yogyakarta: Graha Ilmu.

Somadoyo, S. (2011). Strategi dan Teknik Pembelajaran Membaca. Yogyakarta: Graha Ilmu.

Spielberger, C. D., \& Vagg, P. (Eds). 2004. Test Anxiety: A Transactional Process Model, Test Anxiety Theory, Assessment and Treatment. Washington, D. C: Taylor \&Francis.

Supeno, Suseno, I., Alhamidi, L. A. (2017). Reading strategies as development model English cognition of senior high school students. Indonesian Journal of English Education, 4(1), 84-96.

Suseno, I. (2017). Komparasi karakter butir tes pilihan ganda ditinjau dari teori tes klasik. Faktor Jurnal Ilmiah kependidikan, 4(1), 1-8. 